\title{
ANALISIS DAN PERANCANGAN APLIKASI MOBILE COMMERCE TIKET TRAVEL (M-TICKETING) PADA SMARTPHONE ANDROID (STUDI KASUS : TRAVEL UMBARA TRANS)
}

\author{
Fitri Mintarsih ${ }^{1}$, Rizal Bahawarez ${ }^{2}$, Siti Ulfah Fauziah ${ }^{3}$ \\ ${ }^{1,2,3}$ Program Studi Teknik Informatika, Fakultas Sains dan Teknologi \\ Universitas Islam Negeri (UIN) Syarif Hidayatullah Jakarta \\ J1. Ir. H. Juanda No. 95, Ciputat 15412 Telp. (+62-21) 7493606
}

\begin{abstract}
ABSTRAK
Umbara Trans merupakan perusahaan penyedia jasa travel dengan jangkauan wilayah Jakarta-Bandung. Kemunculan beberapa penyedia jasa travel sejenis menjadikan Umbara Trans harus menyikapi persaingan ketat yang terjadi. Oleh karena itu diperlukan adanya perbaikan strategi dalam bisnisnya agar dapat meningkatkan pelayanan dan kepuasan penggunanya. Berdasarkan hasil wawancara dan penyebaran kuisioner kepada staff dan member Umbara Trans diketahui bahwa perbaikan yang diperlukan berupa inovasi dalam proses promosi, penyebaran informasi, pemesanan dan penjualan tiket yang mudah diakses oleh pengguna jasa, kapanpun dan dimanapun, serta sistem terkomputerisasi yang memudahkan pihak Umbara trans dalam memantau penjualan tiket yang lebih rapi dan dapat dipertanggung jawabkan kebenarannya. Untuk menjawab kebutuhan tersebut maka penulis mengajukan solusi berupa pengimplementasian m-commere tiket travel pada smartphone Android yang dikembangkan dengan metodelogi RAD(Rapid Application Development) dan UML(Unified Modelling Language) sebagai alat bantu dalam pengembangan sistem. Penelitian ini menghasilkan aplikasi M-Commerce Tiket Travel pada Smartphone Android yang berbasis client-server, dimana pada sisi server aplikasi dibangun dalam bentuk website menggunakan bahasa pemrograman PHP serta MySQL untuk proses input data dan manajemen database. Sedangkan pada sisi client berupa mobile aplikasi yang berjalan pada smartphone Android yang digunakan oleh member untuk melakukan pengaksesan informasi (jadwal, armada, lokasi pool terdekat dan harga tiket), promosi, melakukan pemesanan serta pembelian tiket travel.
\end{abstract}

Kata Kunci: M-commerce, Tiket Travel, Smartphone, Android, RAD, UML, PHP, MySQL.

\section{PENDAHULUAN}

\section{A. Latar Belakang}

Travel merupakan salah satu strategi untuk mengatasi kemacetan dengan cara mengingkatkan pelayanan angkutan umum untuk menekan jumlah pengguna kendaraan pribadi (Adistira, 2008). Hasil wawancara dengan pemilik travel Umbara Trans menyatakan, travel merupakan salah satu penyedia layanan transportasi umum yang bertujuan untuk mengurangi tingkat kemacetan.

Keberadaan travel saat ini sangat diminati oleh masyarakat, khusunya untuk tujuan bisnis, pariwisata dan perjalanan lainnya. Hal ini dibuktikan dengan adanya peningkatan jumlah rata-rata penjualan tiket perharinya yang mencetak angka 5.1 pada travel Umbara Trans (Dokumen Umbara Trans, 2013). Pernyataan berikut diperkuat dengan hasil wawancara Detik Finance dengan koordinator Pengembangan Usaha Asita Jakarta Pauline Suharno yang mengungkapkan adanya peningkatan jumlah permintaan jasa travel, khususnya saat menjelang mudik lebaran yang meningkat hingga $150 \%$.

Kenaikan tingkat permintaan terhadap jasa travel menyebabkan adanya persaingan yang ketat antara para penyedia jasa travel. Penyedia jasa travel dituntut untuk inovatif dalam menciptakan diferensiasi pada proses bisnisnya. Hal tersebut merupakan salah satu aspek dari teori pemodelan Five Force CompetitionPorter, yaitu Rivalry Among Existing Competitors. Teori pemodelan Five Force Competition, merupakan tools yang sangat powerfull untuk memahami situasi bisnis yang sedang berjalan sehingga diharapkan dapat mengantisipasi kelemahan dan kesalahan pada pengambilan keputusan dalam menjalankan aktivitas bisnis perusahaan (Harvard Business Rivew, 2008).

Salah satu perusahaan penyedia jasa travel yang diminati adalah Umbara Trans. Umbara Trans merupakan penyedia jasa travel yang terus berupaya untuk meningkatkan kualitas pelayanan. Hal ini dibuktikan dengan penggunaan armada baru yang nyaman, diberikannya 1 tiket gratis kepada pengguna jasa yang telah membeli 10 tiket perjalanan serta ditambahkannya satu loket pool baru untuk meningkatkan dan memperluas jangkauan pelayanan konsumen. Namun disisi lain proses bisnis yang dilakukan belum sepenuhnya tercover dengan baik.

Berdasarkan hasil wawancara dengan pihak Umbara Trans didapati bahwa masalah yang paling sering 
timbul adalah kurangnya kordinasi antar pool dalam memberikan informasi tentang kursi yang telah dipesan, sehingga sering kali konsumen merasa kecewa. Selain itu adanya antrian dalam pelayanan/pemberian informasi dan pemesanan melalui jalur telepon pada waktu padat penumpang juga menjadi kendala yang harus diselesaikan karena tidak sedikit pengguna yang mengeluhkannya saat datang langsung ke pool.

Berdasarkan survey terhadap member ditemukan bahwa $50 \%$ dari pengguna jasa pernah mengalami kesulitan dalam melakukan pemesanan tiket dan $62 \%$ menyatakan pernah menemukan kesulitan dalam mengakses informasi travel. Oleh karena itu penulis merasa perlu membuat sebuah aplikasi yang diharapkan dapat membantu pengguna jasa/member dalam melakukan pemesanan dan mengakses informasi travel. Hal tersebut diperkuat dengan adanya 45 jawaban responden dari total 50 orang responden, yang menyatakan setuju dengan dibuatnya aplikasi tersebut pada perangkat mobile dan 40 orang diantaranya mengatakan siap menggunakan aplikasi tersebut jika telah selesai dibuat.

Permasalahan lain juga ditemukan pada proses pendataan pemesanan yang masih bersifat manual. Tidak adanya integrasi rekap data pemesanan member dikeluhkan sebagai sebab timbulnya masalah tersebut. Hal ini dikarenakan sering adanya perbedaan antara jumlah tiket yang terjual dengan nominal uang yang disetorkan.

Berdasarkan diagram fishbone/ishikawa permasalahan diatas dapat dipetakan sebagai berikut: (Gheorghe: 2010)

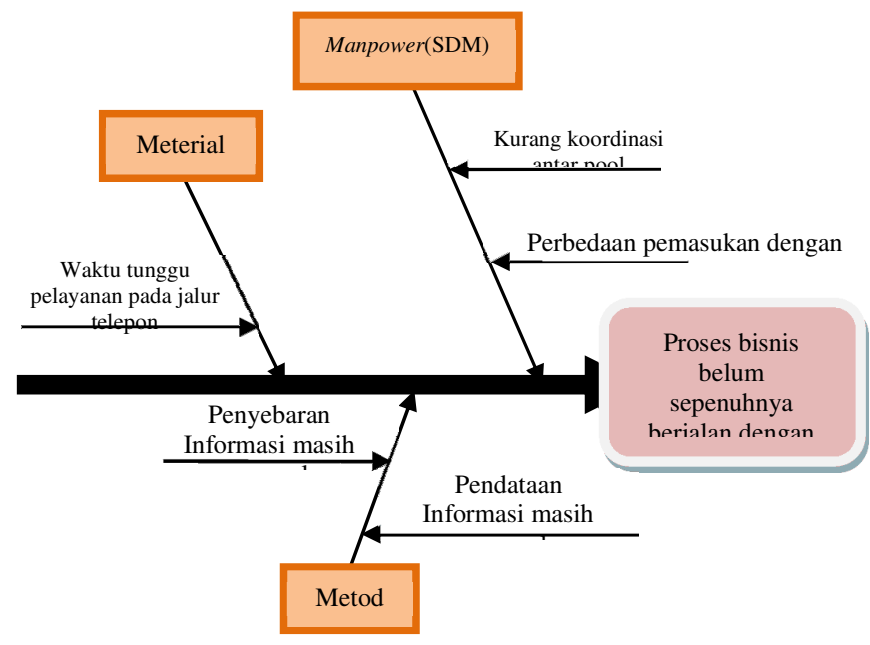

Gambar 1.1. Diagram Fishbone Pada Umbara Trans

Salah satu cara untuk mengatasi masalah-masalah yang ada adalah dengan menggunakan aplikasi $\mathrm{m}$ ticketing. m-ticketing merupakan implementasi dari teknologi M-commerce yang proses atau kegiatan transaksi perdagangannya dilakukan melalui perangkat genggam dengan menggunakan komunikasi, informasi, dan peragkat pembayaran seperti telepon selular dan palmtop (Mar, 2003). Pada kasus ini Mobile commerce digunakan sebagai sarana komunikasi penyebaran informasi travel dan sebagai fasilitas pemesanan tiket travel yang dapat digunakan kapan pun dan dimana pun, serta dapat memudahkan dalam melihat aktivitas pemesanan member.

Selain berupaya dalam memecahkan masalahmasalah yang ada, Umbara Trans juga memerlukan adanya inovasi baik untuk menjaga kesetiaan pelanggan maupun untuk mendapatkan pelanggan baru. Dalam penelitian ini, inovasi yang diajukan berupa kemudahan dalam mengakses berita dan promosi, penyampaian keluhan pelanggan serta pencarian lokasi pool terdekat menggunakan Global Positioning System (GPS) yang telah terintegrasi pada smartphone yang akan dikemas dalam modul yang ada pada aplikasi $m$-ticketing yang akan dibangun.

Aplikasi m-ticketing yang dibangun akan diterapkan pada perangkat smartphone. Smartphone merupakan salah satu teknologi pada perangkat mobile yang sedang berkembang saat ini. Fungsi smartphone tersebut ditujukan untuk memenuhi kebutuhan informasi secara cepat dan mudah. Kehadiran smartphone saat ini ditujukan untuk menggantikan fungsi PC agar lebih fleksibel khususnya dalam mengakses jaringan internet.

Perkembangan smartphone saat ini diikuti dengan hadirnya berbagai sistem operasi dan fitur canggih. Salah satu sistem operasi pada smartphone yang perkembangannya sangat signifikan dibandingkan dengan sistem operasi lainnya menurut gartner.com adalah Android. Pengembangan teknologi Android diimbangi dengan meningkatnya minat pengguna teknologi tersebut. (Gan et al. 2010)

Aplikasi yang akan dibangun merupakan aplikasi yang memudahkan bagi penggunanya karena hanya dengan menggunakan device android yang terkoneksi internet, pengguna jasa dapat memesan, membeli tiket dan mengakses promosi yang ditawarkan dengan mudah serta dapat memberikan kritik maupun saran kepada penyedia jasa kapanpun dan di manapun tanpa harus datang langsung ke loket pool atau pun menunggu pelayanan melalui jalur telepon. Aplikasi ini tidak hanya bermanfaat untuk pengguna namun juga dapat dirasakan perusahaan dalam membantu memperluas jangkauan promosi.

\section{B. Perumusan Masalah}

Berdasarkan penjabaran latar belakang diatas maka permasalahan yang dapat dikaji dalam penelitian adalah sebagai berikut:

1. Bagaimana membuat sebuah media pelayanan jasa travel yang mudah dan efisien dalam menyampaikan informasi travel(jadwal 
keberangkatan, harga, lokasi pool, lokasi pool terdekat dan armada) ke pengguna jasa?

2. Bagaimana membuat aplikasi yang dapat mempermudah proses pemesanan dan pembelian tiket serta dapat digunakan kapan pun dan dimanapun?

\section{Batasan Masalah}

Agar penelitian yang dilakukan lebih fokus dan terarah maka penulis memberikan batasan berdasarkan masalah yang telah ditentukan, yaitu :

1. Aplikasi yang dibangun hanya digunakan untuk pemesanan tiket pada 1 instansi travel yaitu Travel Umbara Trans.

2. Aplikasi yang dibangun tidak mencakup pada keamanan data dan sistem.

3. Aplikasi hanya dapat berfungsi sempurna jika terhubung dengan internet.

4. Aplikasi yang dibangun hanya terdiri dari proses: a. Informasi jadwal keberangkatan, rute keberangkatan, armada yang digunakan, lokasi pool, pencarian lokasi pool terdekat, promosi yang diberikan, pemesanan tiket serta konfirmasi pembayaran.

b.Pengelolaan data member, pelayanan keluhan pelanggan melalui telepon dan sms.

5. Proses konfirmasi pembayaran dilakukan manual oleh admin dengan memeriksa kesamaan antara laporan sms banking dengan kode transfer yang diinput oleh member.

6. Hak akses pada aplikasi ini mencakup admin sebagai pemilik hak akses penuh untuk mengelola aplikasi dan member yang hanya dapat menjalankan aplikasi pada smartphone saja.

\section{Manfaat dan Tujuan Penelitian}

Manfaat penelitian ini adalah untuk mempermudah para pengguna jasa travel dalam memperoleh informasi jadwal keberangkatan, rute perjalanan, lokasi pool terdekat dan mempermudah dalam pemesanan tiket serta sebagai sarana promosi dari pihak penyedia jasa travel.

Tujuan penulisan skripsi ini adalah :

1. Membangun aplikasi m-ticketing pada platform android sebagai media penyampaian informasi travel yang mudah diakses dan evisien tanpa harus membuang waktu untuk datang langsung ke loket pool ataupun menunggu pada jalur telepon.

2. Membangun aplikasi pemesanan dan pembelian tiket yang dapat diakses dimana pun dan kapan pun tanpa harus menunggu pelayanan dari petugas loket.

\section{LANDASAN TEORI}

\section{A. Rancang Bangun}

Perancangan merupakan serangkaian prosedur untuk menerjemahkan hasil analisis dari sebuah sistem ke dalam bahasa pemrograman untuk mendeskripsikan dengan detail bagaimana komponen-komponen sistem diimplementasikan (Pressman, 2002). Sedangkan pengertian bangun atau pada buku karya (Pressman, 2002) dituliskan sebagai pembangunan sistem adalah kegiatan menciptakan sistem baru maupun mengganti atau memperbaiki sistem yang telah ada baik secara keseluruhan maupun sebagian.

\section{B. Aplikasi}

Aplikasi merupakan sebuah produk yang dikembangkan oleh pengembang perangkat lunak (software engineer) yang mencakup program yang dapat dieksekusi oleh komputer dengan berbagai ukuran dan arsitektur (Pressman,2002). Menurut (Jogiyanto, 2004), aplikasi merupakan program yang berisikan perintah-perintah untuk melakukan pengolahan data. Sedangkan menurut (Nugroho, 2004), aplikasi adalah program komputer yang dibuat untuk menolong manusia dalam melaksanakan tugas tertentu. Berdasarkan pernyataan-pernyataan tersebut, penulis menyimpulkan bahwa aplikasi adalah program yang dirancang oleh pengembang perangkat lunak dalam bentuk perintah-perintah khusus untuk mengoptimalkan proses pengolahan data dalam melaksanakan tugas trertentu.

\section{Mobile Commerce}

Mobile commerce merupakan jenis baru dari $e$ commerce yang menggunakan perangkat mobile untuk melakukan transaksi (Lim et al, 2003). Kelahiran mobile commerce dipicu oleh tingginya tingkat penetrasi handphone di seluruh dunia (Hartati, 2011).

Menurut (Mar, 2003), mobile commerce adalah proses atau kegiatan transaksi perdagangan melalui perangkat genggam dengan menggunakan komunikasi, informasi, dan perangkat pembayaran, seperti telepon seluler dan palmtop. Mobile commerce berfungsi untuk memberikan informasi yang tepat dan update mengenai suatu bisnis atau kegiatan perdagangan, kapan pun dan dimana pun sesuai dengan kebutuhan pengguna, namun hal tersebut hanya dapat dicapai jika pengguna memiliki kemampuan untuk mengakses internet (Lim et al. 2003).

\section{Fitur Mobile Commerce}

Secara umum $m$-commerce memiliki kesamaan dengan e-commerce, namun $m$-commerce memiliki fitur yang tidak tersedia pada e-commerce, diantaranya sebagai berikut: (Lim et al. 2003)

1. Ubiquity, merupakan keuntungan untama dari mcommerce untuk pengguna. M-commerce dapat digunakan dimana pun pengguna berada dan dalam situasi apa pun. Dengan kata lain layanan $m$ commerce tersedia kapan pun dan dimana pun dibutuhkan, melalui koneksi internet pada perangkat mobile yang digunakan. 
2. Reachability, melalui pernangkat mobile pengguna dapat bertransaksi dan berkomunikasi dengan pihak lain yang tidak terjangkau karena perbedaan ruang dan waktu.

3. Localization, m-commerce meyediakan layanan berbasis lokasi yang dibutuhkan oleh pengguna berdasarkan lokasi fisik penggunanya (location based servers). Contoh pada penelitian ini: pengguna dapat mengkses lokasi pool terdekat dari posisinya saat menggunakan aplikasi $m$-commerce.

4. Personalization, Sejumlah besar informasi, layanan, dan aplikasi saat ini sudah tersedia di Internet, namun relevansi informasi yang diterima pengguna sangatlah penting. Karena pemilik perangkat mobile sering membutuhkan pengaturan aplikasi dan layanan yang berbeda, maka aplikasi $m$-commerce dirancang agar dapat dipersonalisasi sehingga informasi atau pelayanan dapat diberikan dengan cara yang tepat dan sesuai dengan spesifikasi pengguna.

5. Dissemination, pengguna dapat menerima dan menyebarluaskan informasi secara cepat dan kini (saat itu juga) dengan menggunakan beberapa infrastruktur nirkabel yang mendukung pengiriman data secara simultan ke semua pengguna ponsel dalam suatu wilayah geografis tertentu.

E. Tiket

Tiket merupakan suatu alat atau media yang digunakan oleh perusahaan tertentu sebagai pengganti uang langsung. Tiket biasanya berupa kertas yang didalamnya terdapat item - item tertentu yang menunjukan suatu nilai (Wikipedia: 2013). Menurut Kamus Besar Bahasa Indonesia yang dimaksud tiket adalah "sesuatu yang dianggap sebagai alat pembayaran yang digunakan oleh suatu alat transportasi yang ada". Pada penelitian ini, melalui tiket travel, pengguna jasa dapat mengetahui informasi tujuan keberangkatan, jam keberangkatan, dan no tempat duduk yang dipesan.

\section{F. Travel}

Travel adalah sebuah layanan angkutan penumpang dari terminal/pool kota asal ke terminal/pool kota tujuan sesuai jurusan yang dilayani travel tersebut. Layanan travel memiliki beberapa keuntungan bagi konsumen antara lain lokasi pool berada pada lokasi strategis, pool/outlet yang memiliki standar kenyamanan, keberangkatan terjadwal dan on time, seat penumpang yang terbatas, driver yang santun dengan melalui seleksi penerimaan yang ketat dan training yang berkelanjutan serta perlindungan asuransi kepada penumpang.

\section{G. Smartphone \\ Smartphone merupakan istilah dari handphone(cellular phone) dengan kemampuan multimedia dan computing yang lebih advance}

daripada handphone pada umumnya. Ini karena adanya kombinasi antara sistem operasi, hardware dan aplikasi yang jauh lebih bagus pada smartphone. Terdapat banyak platform smartphone pada saat ini, dilihat dari sistem operasi dan spesifikasi hardware yang digunakan. Misalnya platform Symbian, RIM, Windows Phone, iPhone, dan Android (Nielsen, 2011).

Selain itu Pei Zheng dan Lionel Ni mendefinisikan smartphone sebagai kelas baru pada teknologi telepon seluler yang mampu memfasilitasi akses data dan pemrosesan informasi dengan kemampuan komputasi secara signifikan. Selain memiliki fungsi tradisional yang terdapat pada telepon selular seperti menelepon dan sms, smartphone dilengkapi dengan manajemen informasi personal (PIM) dan komunikasi ke beberapa media akses nirkabel.

Sebuah smartphone biasanya mendukung satu atau lebih teknologi nirkabel jarak pendek seperti Bluetooth dan inframerah sehingga memungkinkan untuk mentransfer data melalui koneksi nirkabel di samping koneksi untuk koneksi data seluler. Smartphone dapat memberikan mobilitas layaknya subuah komputer, akses data dimana-mana dan kecerdasan yang menyeluruh untuk hampir setiap aspek proses bisnis dan kehidupan sehari-hari. Sesuai dengan visi dari smartphone "kapan saja, dimana saja dari perangkat" (Zheing, 2006). Contoh-contoh Smartphone berbasis operating system adalah Android, Blacberry, iPhone, Smartphone berbasis Symbian, Smartphone berbasis BREW dan Smartphone berbasis Windows Mobile.

Aplikasi khas yang terdapat di dalam ponsel pintar ini meliputi, game sederhana, built-in dengan kamera, pemutaran audio/video dan rekaman, instant messaging, e-mail dan akses internet nirkabel. Selain itu ponsel cerdas ini bisa digunakan sebagai terminal untuk layanan e-commerce, aplikasi perusahaan, dan layanan berbasis local (Location Based Services). Singkatnya smartphone menjadi masa depan pada teknologi seluler saat ini karena menawarkan berbagai fitur dalam meningkatkan kemampuan nirkabel, daya komputasi dan penyimpanan on-board.

\section{H. M-ticketing(Mobile Ticketing)}

Mobile ticketing merupakan aplikasi dari mobile commerce yang memberikan fasilitas kepada pengguna untuk memesan,membayar, mendapatkan dan memvalidasi tiket dengan menggunakan perangkat mobile. (kurkovsky: 2007)

\section{Android}

Android dirilis oleh Google pada bulan November 2007 dengan tujuan menjadi tempat open source untuk pengembangan perangkat lunak pada ponsel. Platform Android dirilis di bawah Open Handset Alliance. Android adalah open source ponsel sistem operasi berbasis kernel Linux. Sistem operasi android memfasilitasi bagi para pengembang untuk menulis 
kode Java menggunakan Java libraries yang dikembangkan oleh google (Gronli et all, 2010). Di dalamnya terdapat sistem operasi, middleware, dan key application.

\section{J. API (Application Programming Interface)}

Sebuah API dapat memberikan kemampuan bagi pengembang untuk mengakses data dan layanan yang dibutuhkan untuk membuat sebuah aplikasi secara cepat. Sebut saja seperti Facebook API dan Twitter API yang sudah sangat dikenal dikalangan pengembang. "API stands for application programming interface. An API can provide a hook for colleagues, partners, or third-party developers to access data and services to build applications such as iPhone apps quickly. The Twitter and Facebook APIs are famous examples. "(Jacobson, et al., 2012:4)

Penelitian ini memanfaatkan API yang disediakan oleh Google untuk mencari lokasi pool terdekat dengan pengguna dan penandaan dalam peta. API yang digunakan adalah Google Direction API.

\section{K. Definisi Lokasi Pool Terdekat}

Dalam aplikasi ini peneliti mendefinisikan lokasi pool terdekat hanya untuk lokasi pool yang berjarak radius 5 kilometer dari tempat pengguna aplikasi berada. Tiap $1^{0}$ latitude $= \pm 111 \mathrm{~km}$. “.., 1 degree of latitude can be considered as equal to 60 nautical miles (111,12 km),..” (Cutler, 2004:11). Dengan demikian dapat dihitung bahwa 1 kilometer $= \pm 0,009^{\circ}$. Teori ini akan digunakan dalam pembuatan aplikasi.

\section{L. $R A D$ (Rapid Application Development)}

Rapid Application Development (RAD) adalah suatu pendekatan berorientasi objek terhadap pengembangan sistem yang mencakup suatu metode pengembangan serta perangkat-perangkat lunak. Metode pengembangan Rapid Applicaion Development (RAD) yang digunakan dalam penulisan ini memiliki tahapantahapan (fase-fase) sebagai berikut: (Kendall \& Kendall, 2010)

1. Perencanaan Syarat-Syarat

Pada fase ini penulis menganalisa dan mengidentifikasi tujuan-tujuan aplikasi dan syarat-syarat informasi yang dihasilkan dari tujuan tersebut. Orientasi dari fase ini adalah menyelsaikan masalah-masalah yang timbul pada saat menganalisa aplikasi yang akan dibangun.

2. Workshop Design

Fase ini adalah fase untuk merancang dan memperbaiki yang dapat digambarkan sebagai workshop. Selama workshop design RAD, pengguna merespon prototipe sistem yang ada dan menganalisa, memperbaiki modul-modul yang dirancang menggunakan perangkat lunak.

3. Fase Implementasi

Analisis bekerja secara intens untuk merancang aspek-aspek bisnis dan non teknis dari aspek bisnis. Segera setelah aspek-aspek ini disetujui dan sistem dibangun dan di-sharing, sistem kemudian diujicoba.

\section{Porter's Five Forces Analysis}

Berdasarkan Porter (1980, 1985) dalam teori Five Force Analysis, analisis strategi bisnis suatu perusahaan dapat diukur dengan mengetahui lima kekuatan utama, seperti: ancaman pendatang baru, persaingan antara perushaan yang ada dalam suatu industri, ancaman produk/jasa pengganti (subtitusi), kekuatan kosumen, kekuatan pemasok (Gambar 2.7).

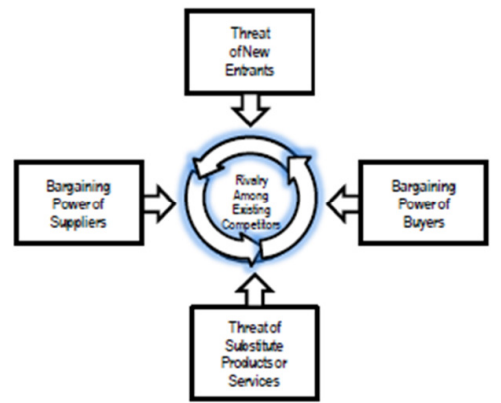

Gambar 2.7. The Five Forces that Shape Industry Competition

Analisis five force merupakan analisis yang menentukan intensitas dalam persaingan industri, profitabilitas, the strongest force or force are governing dan menjadi sangat penting dalam merumuskan strategi-strategi perusahaan. Porter's Five Forces Analysis juga merupakan alat yang cukup sederhana dan powerful untuk mengerti atau mengetahui kekuatan suatu situasi bisnis yang akan dijalankan kelak. Hal ini menjadi penting, disebabkan analisis Porter's Five Forces dapat membantu pengusaha untuk mengerti pada dua hal yaitu kekuatan dari posisi persaingan saat ini dan kekuatan dari posisi perusahaan dalam menghadapinya.

1. Threat of new entrants (pendatang baru), kekuatan suatu industri juga dapat dipengaruhi oleh kemampuan pengusaha-pengusaha lain untuk memasuki industri tersebut. Jika industri yang dimasuki tersebut tidak membutuhkan waktu yang lama, biaya yang besar,maka mudah bagi pemain baru untukk memasuki industri ini.

2. Bargaining Power of Supplier (kekuatan pemasok). Dalam hal ini, pebisnis harus mengetahui bagaimana kemudahaan supplier dalam memberikan harga. Hal ini tentunya disebabkan oleh beberapa hal, seperti: berapa banyak supplier pada tiap proses, keunikan pada produk atau jasa yang mereka tawarkan, kekuatan mereka dan kontrol yang dapat kita lakukan, biaya penganti pemasok satu ke pemasok yang lain, dan lain-lain. Sedikitnya pemasok yang dapat dipilih dalam industri itu, maka perusahaan akan lebih 
membutuhkan pemasok, sehingga pemasok dapat memiliki kekuatan terhadap perusahaan tersebut.

3. Threat of substitution (subsitusi). Hal ini berdampak pada kemampuan konsumen untuk menemukan cara yang berbeda dari yang dilakukan oleh perusahaan. Dalam hal ini, jika konsumen memiliki kemampuan untuk mendapatkan barang dan jasa lain yang dapat memiliki manfaat yang sama dengan barang dan jasa yang dimiliki oleh perusahaan. Gambar 2.7 menunjukkan interaksi antara kekuatan kompetitif yang berbeda .

4. Competitive rivalry (kekuatan persaingan). Hal yang terpenting dalam kekuatan ini adalah berapa banyak pesaing dan kemampuan pesaing-pesaing tersebut. Jika suatu industri terdiri dari pemainpemain yang banyak, dan mereka menawarkan barang dan jasa yang sama menariknya, maka perusahaan dalam industri ini memiliki kekuatan yang kecil.

5. Bargaining Power of Buyers (kekuatan Konsumen). Dalam hal ini, pengusaha harus mengetahui seberapa mudah konsumen dapat menurunkan harga. Hal ini juga disebabkan oleh beberapa hal lain, seperti: seberapa besar konsumen, seberapa penting dari tiap konsumen dalam bisnis ini, seberapa besar biaya perpindahan (switching cost) dari barang dan jasa yang ditawarkan perusahaan kepada barang dan jasa subsitusi lain. Perusahaan yang hanya memiliki sedikit konsumen, maka konsumen akan memiliki kekuatan untuk mempengaruhi harga dalam perusahaan.

\section{N. Pengujian Sistem}

Dalam pengujian sistem terdapat dua metode pengujian yang mendominasi yaitu black-box dan white-box.

\section{Black-box Testing}

Black-box testing adalah tipe testing yang memperlakukan perangkat lunak yang tidak diketahui kinerja internalnya. Sehingga para tester memandang perangkat lunak layaknya "kotak hitam" yang tidak penting dilihat isinya, tapi cukup dikenai proses testing di bagian luar. (Rizky, 2011:264)

Beberapa keuntungan yang diperoleh dari jenis testing ini antara lain :

1. Anggota tim tester tidak harus memiliki kemampuan teknik di bidang pemrograman.

2. Kesalahan atau bug seringkali ditemukan oleh komponen tester yang berasal dari pengguna.

3. Hasil black-box testing dapat memperjelas kontradiksi ataupun kerancuan yang mungkin timbul dari eksekusi sebuah perangkat lunak.

4. Proses testing dapat dilakukan lebih cepat dibandingkan white-box testing.

\section{White-box Testing}

White-box testing secara umum merupakan jenis testing yang lebih berkonsentrasi terhadap "isi" dari perangkat lunak itu sendiri. Jenis pengujian ini lebih banyak berkonsentrasi kepada source code dari perangkat lunak yang dibuat sehingga membutukan proses testing yang jauh lebih lama dan lebih "mahal" dikarenakan membutuhkan ketelitian serta keampuan teknik pemrograman dari para tester. (Rizky, 2011:264).

Jenis testing ini juga membutuhkan inputan data yang dianggap cukup memenuhi syarat agar perangkat lunak benar-benar dinyatakan memenuhi kebutuhan pengguna.

Prinsip dari keluaran tipe testing ini adalah sebagai berikut:

1. Menjamin bahwa setiap alur program yang independen (dalam bentuk modul, form, prosedur, class, dan lainnya) telah dites minimal satu kali.

2. Telah melakukan testing terhadap semua kondisi percabangan dengan nilai true dan false.

3. Telah melakukan testing terhadap semua jenis perulangan dengan kondisi normal dan kondisi yang dianggap melampaui batas perulangan (umumnya kondisi yang melampaui batas harus dibatasi oleh prosedur tertentu).

4. Telah melakukan testing terhadap strukur data internal (seperti variabel) agar terjaga validasinya.

Dalam penelitian ini, Penulis lebih memilih untuk mengembangkan aplikasi dengan menggunakan black-box testing karena proses pengujian dengan metode black-box lebih mudah dan lebih cepat.

\section{PeRAnCANGAn Sistem}

Analisis Sistem yang berjalan berdasarkan teori five force competition - Porter

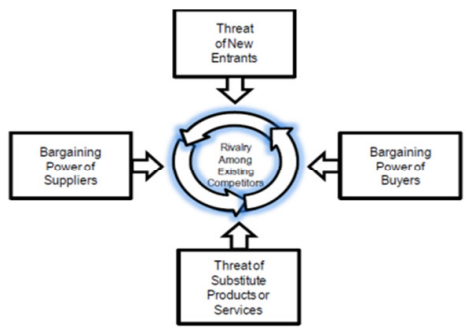

Gambar 4.2. Five Force Competition Diagrams

\section{Ancaman Pendatang Baru}

Ancaman pendatang baru merupakan faktor penyebab adanya persaingan dalam suatu perusahaan. Namun ancaman tersebut dapat diatasi dengan cara:

\section{1. loyalitas pelanggan}

Menciptakan kesetiaan para pengguna jasa travel umbara trans dalam menggunakan pelayanan yang tersedia karena hal tersebut dapat dijadikan penghalang untuk masuknya pendatang baru. 


\section{Diferensiasi Produk}

Produk yang ditawarkan oleh perusaan jasa travel pada umumnya sama, yaitu tiket perjalanan. Oleh karena itu diverensiasi produk diwujudkan dengan cara memberikan penawaran khusus untuk member yang masih aktif, dan memberikan inovasi dalam pelayanannya.

\section{Akses ke saluran distribusi}

Dengan aplikasi yang akan dibangun diharapkan pihak umbara trans dapat dengan mudah mendistribusikan tiket dijual secara langsung kepada member yang dapat dilakukan dimana pun dan kapan pun tanpa harus datang ke lokasi pool pemesanan.

\section{Kekuatan penawaran pembeli}

Dalam menjaga kekuatan penawaran pembeli PT.Umbara Trans menjual tiket dengan harga standar, namun member akan mendapatkan promosi khusus untuk setiap pembelian 15 tiket, pembeli akan mendapatkan souvenir dari umbara trans. Selain itu, diharapkan dengan aplikasi yang akan dibangun, PT.Umbara Trans dapat memberikan akses informasi yang lengkap dan mudah kepada pembeli.

\section{Ancaman Produk atau Jasa pengganti}

Ancaman jasa pengganti dapat timbul bila pelayanan jasa yang diberikan kurang memuaskan, adanya fasilitas bus Jakarta-bandung yang memberikan harga murah dapat meningkatkan ancaman terjadinya jasa pengganti sehingga pihak travel, khususnya PT.Umbara Trans dituntut untuk memberikan pelayanan terbaik kepada para member agar member tidak beralih pada jasa lainnya.

\section{Kekuatan Penawaran Pemasok}

Kekuaran penawaran pemasok dibentuk dengan dibukanya cabang-cabang baru loket penjualan tiket. Namun pembukaan cabang baru yang memerlukan modal dan biaya yang besar dapat digantikan dengan aplikasi $m$-commerce yang akan dibangun.

\section{Persaingan antara perusahaan yang ada}

Dalam menjalankan proses bisnisnya umbara trans memiliki banyak pesaing seperti travel bimo trans, daytrans, cipaganti dan lain sebagainya. Untuk mengatasi persaingan yang ada maka umbara trans menciptakan diferensiasi atau pembeda baik dalam jangkauanrute perjalanan, pembukaan cabang baru, penggunaan armada baru, serta ditambahkan dengan adanya inovasi dalam mencapai kepuasan pelanggan melalui pemberian akses informasi yang dapat digunakan kapan pun dan dimanapun serta memberikan kemudahan kepada member dalam menyampaikan keluhan dan saran kepada pihak travel.

\section{Perancangan Usecase Diagram}

Berikut adalah usecase diagram yang dirancang.

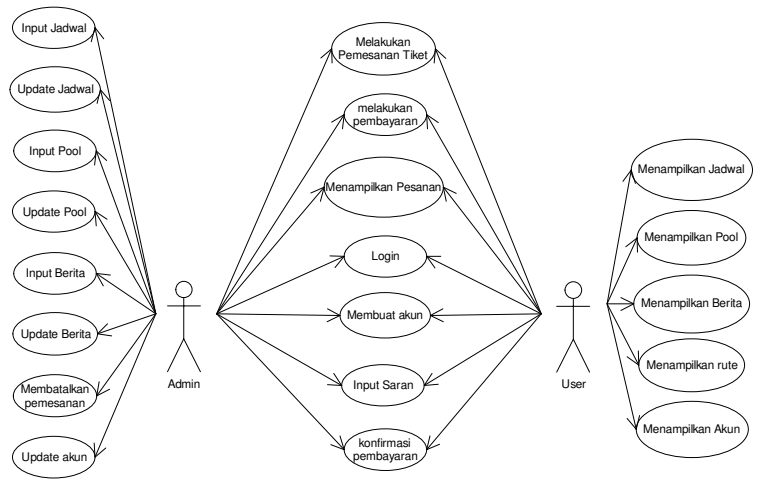

Gambar 3.1 Usecase diagram

\section{Perancangan Arsitektur Aplikasi}

Perancang sistem aplikasi yang akan dibuat oleh penulis dalam penelitian ini adalah sebagai berikut:

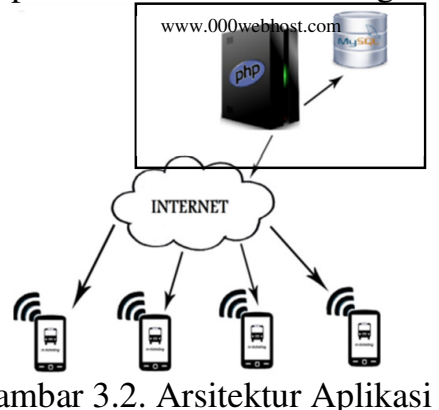

Aplikasi yang akan dibuat adalah aplikasi Mobile Commerce tiket travel yang selanjutnya akan disebut $\mathrm{m}$-ticketing. Aplikasi $\mathrm{m}$-ticketing berfungsi untuk membantu member dalam mengakses informasi tentang travel, pemesanan tiket perjalanan, dan sebagai inovasi baru yang diberikan oleh perusahaan untuk menarik calon pelanggan baru. Aplikasi mticketing ini merupakan aplikasi client-server. Pembangunan aplikasi m-ticketing ini dibedakan berdasarkan penggunanya, yaitu admin berperan pada sisi server(web application) dan member berperan pada sisi client(Android native application).

Proses m-ticketing pada server berupa pengelolaan data rute, jadwal keberangkatan, lokasi pool, berita tentang travel, pemesanan serta pembayaran yang dapat dikases oleh admin melalui website browser. Pada sisi client, member menggunakan aplikasi native android dalam proses pemesanan dan pencarian informasi. Setiap proses yang terjadi pada aplikasi mobile diteruskan dengan mengakses data pada web application yang dibuat dengan bahasa pemrograman php dan didukung dengan database mysql melalui jaringan internet. 


\section{ANALISIS PERbandingan PEMESANAN SEBELUM(MELALUI TELEPON DAN LOKET POOL) DAN SESUDAH MENGGUNAKAN APLIKASI}

Tabel 3.1 Perbandingan Pemesanan melalui telepon dan loket pool dengan aplikasi $m$-commerce tiket travel Umbara Trans

\begin{tabular}{|c|c|c|c|}
\hline & Melalui Telepon & Melalui Loket Pool & $\begin{array}{l}\text { Apliksi } \\
\text { Mobile }\end{array}$ \\
\hline $\begin{array}{l}\text { Waktu } \\
\text { Pelayanan } \\
\text { Informasi } \\
\text { dan } \\
\text { Pemesanan }\end{array}$ & $\begin{array}{l}\text { Ditentukan } \\
\text { (Jam } 04.00 \text { s.d Jam 20.00) }\end{array}$ & $\begin{array}{l}\text { Ditentukan } \\
\text { (Jam } 04.00 \text { s.d Jam } \\
20.00 \text { ) }\end{array}$ & $\begin{array}{l}\text { Tidak } \\
\text { Ditentukan, } \\
\text { dapat diakses } \\
\text { kapanpun }\end{array}$ \\
\hline $\begin{array}{l}\text { Tempat } \\
\text { Pemesanan }\end{array}$ & Dapat diakses dimana pun & $\begin{array}{l}\text { Seluruh Pool } \\
\text { Umbara Trans }\end{array}$ & $\begin{array}{l}\text { Dapat diakses } \\
\text { dimana pun }\end{array}$ \\
\hline $\begin{array}{l}\text { Biaya } \\
\text { Pemesanan } \\
\text { Di Luar } \\
\text { Harga Tiket }\end{array}$ & $\begin{array}{l}\text { Penelitian dilakukan menggunakan } 3 \\
\text { provider jaringan selular yang paling } \\
\text { diminati masyarakat Indonesia/Mei } \\
2013 \text { (http://tekno.kompas.com) } \\
\text {-Telkomsel- } \\
\text { Waktu pemesanan:5menit } \\
\text { BiayaPanggilan/pemesanan: } \\
\text { Rp. 4050,- } \\
\text {-Indosat- } \\
\text { Waktu pemesanan:5menit } \\
\text { BiayaPanggilan/pemesanan: } \\
\text { Rp. 5000,- } \\
\text {-3- } \\
\text { Waktu pemesanan:5menit } \\
\text { BiayaPanggilan/pemesanan: } \\
\text { Rp. 2500,- }\end{array}$ & $\begin{array}{l}\text { Penelitian dilakukan } \\
\text { dengan mengunjungi } \\
\text { loket pool terdekat } \\
\text { dari tempat tinggal } \\
\text { peneliti } \\
\text { Biaya transport untuk } \\
\text { mengakses lokasi } \\
\text { Pool } \\
\text { (Rp. } 6000,- \text { ) }\end{array}$ & Gratis \\
\hline $\begin{array}{l}\text { Waktu Yang } \\
\text { Dibutuhkan } \\
\text { Untuk } \\
\text { Melakukan } \\
\text { Pemesanan }\end{array}$ & $\begin{array}{l}\text { Waktu tunggu pelayanan+waktu } \\
\text { pelayanan } \\
\text { Pemesanan I (pukul 10.00): } \\
\text { 18detik + 4menit 3detik = 4menit } \\
\text { 31detik } \\
\text { Pemesanan II(pukul13.00): } \\
\text { Panggilan I: } \\
\text { 35detik (Tidak ada respon) } \\
\text { Panggilan II: } \\
\text { 35detik (Tidak ada respon) } \\
\text { Panggilan III: } \\
\text { 18detik + 4menit = 4menit 18detik } \\
\text { PemesananIII(pukul 19.00): } \\
5 \text { dtk + 5mnt=5menit 5detik }\end{array}$ & $\begin{array}{l}\text { Waktu menuju pool } \\
\text { terdekat+waktu } \\
\text { menunggu pelayanan } \\
\text { di pool } \\
20 \text { menit+3menit = } \\
23 \text { menit }\end{array}$ & $\begin{array}{l}\text { Tidak } \\
\text { memerlukan } \\
\text { waktu tunggu } \\
\text { untuk } \\
\text { melakukan } \\
\text { pemesanan } \\
\text { dan } \\
\text { mendapatkan } \\
\text { informasi, } \\
\text { dapat diakses } \\
\text { langsung } \\
\text { melalui device } \\
\text { member }\end{array}$ \\
\hline
\end{tabular}

\section{Pengujian Sistem}

Pengujian Kesesuaian Fitur Pada Sistem Yang Dibangun (M-Commerce Tiket Travel Umbara Trans) Dengan Fitur Yang Harus Ada Pada $M$ Commerce dilakukan

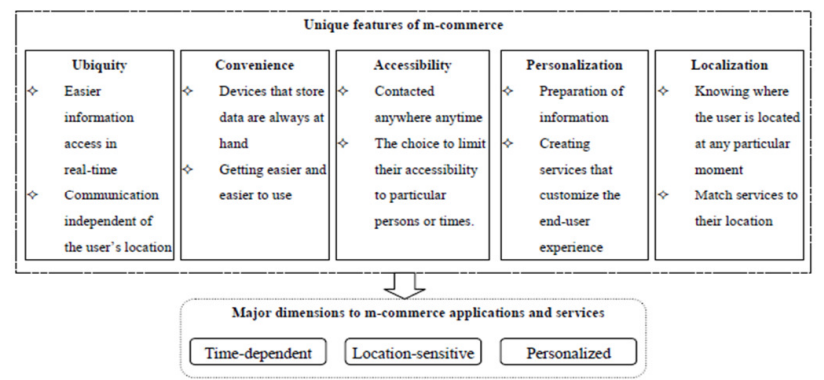

Gambar 4.13 Implementasi Aplikasi Mobile

Tabel 4.1 Tabel Analisis Fitur

\begin{tabular}{ll}
\hline \multicolumn{1}{c}{ Fitur } & \multicolumn{1}{c}{ M-Commerce Tiket Travel Umbara } \\
Trans
\end{tabular}

Berdasarkan penjabaran diatas maka dapat disimpulkan bahwa aplikasi yang dibangun sesuai dengan ketentuan fitur m-commerce.

\section{KESIMPULAN DAN SARAN}

\subsection{Kesimpulan}

Berdasarkan pembahasan yang telah dilakukan pada BAB IV dapat ditarik kesimpulan sebagai berikut:

1. Aplikasi pemesanan yang telah dibangun merupakan aplikasi yang efisien terhadap waktu dan biaya seperti yang telah dijabarkan pada tabel 3.1

2. Aplikasi M-Commere Tiket Travel Umbara Trans dapat digunakan untuk mempermudah member dalam melakukan pemesanan dan pembelian tiket yang dapat dilakukan kapan pun, dimana pun seperti yang telah diujikan pada tabel 4.1

\subsection{Saran}

Sistem yang dibangun masih memiliki kekurangan, untuk perbaikan pada pengembangan selanjutnya penulis memberikan saran, diantaranya:

1. Pada pengembangan selanjutnya diharapkan lebih memperhatikan keamanan sistem. 
2. Aplikasi hanya berjalan pada smartphone dengan sistem operasi Android, untuk pengembangan selanjutnya dapat dibangun pada sistem operasi mobile lainnya.

3. Selanjutnya pada sisi admin dapat dibangun modul untuk pengolaan keuangan pada dari hasil proses pemesanan.

4. Tampilan aplikasi mobile yang dibangun masih sangat standar walaupun semua fungsi yang dibutuhkan telah terpenuhi, oleh karena itu untuk pengembangan slanjutnya diharapkan lebih memperhatikan tampilan dan kesesuaian pada berbagai jenis ukuran device pengguna untuk menambah kenyamanan pengguna dalam mengoperasikan aplikasi yang dibangun.

\section{DAFTAR PUStaka}

[1] Barnett, N., Hodges, S., dan Wilshire, M. J. 2000. Mobile commerce: An Operator's Manual. The McKinsey Quaterly, Volume 3. Pp: 163-173.

[2] Developer.Google. 2013. Introduction to the Google Maps Android API v2. [Online] Tersedia: https://developers.google.com/maps/documentat ion/android/intro [4 Maret 2013]

[3] Deviana, Hartati. 2011. Penerapan XML Web service Pada Sistem Distribusi Barang, Jurnal Generic, Vol. 6, No. 2, Juli 2011, pp. 55 62, ISSN: 1907-4093.

[4] Fiqri,Elsa. 2012. Aplikasi Pemesanan Tiket Periangan Inter City Berbasis Mobile Android. Bandung: Universitas Komputer Indonesia.

[5] Gheorghe, Ilie.Et. al. 2010. APPLICATION OF FISHBONE DIAGRAM TO DETERMINE THE RISK OF AN EVENT WITH MULTIPLE CAUSES.Romania: Management research and practice vol.2 Issue 1.

[6] Grønli,T., Hansen, J., Ghinea, G.2010.Android vs Windows Mobile vs Java ME: A comparative Study of Mobile Development Environments. PETRA ' 10.

[7] Gulo, W. 2003. Metodelogi Penelitian. Jakarta: PT. Gramedia Pustaka Utama.

[8] Heaton, Jeff. 2006. Java for the Beginning Programmer. Heaton Research, Inc.

[9] Jacobson, Daniel. Et. al. 2012. APIs: A Strategy Guide [Online] Tersedia: http://it-ebooks.info/ go.php?id=349-1371404628-2b774a8b7 caecb59df4be02349578853 [16 Juni 2013]

[10] Jogiyanto, Hartono. 2004. Pengenalan Komputer. Yogyakarta: C.V.ANDI OFFSET.

[11] Kurkovsky, Stan. 2007. Mobile Commerce Technologies. Cairo-Egypt: International
Conference on Information and Communication Technology (ICICT 2007).

[12] Lim, E.P., Shen, Z., dan Siau, K. 2003. Mobile Commerce: Current States and Future Trends. United State Of America: Idea Group Publishing.

[13] Mariga, J. 2003. Managing E-Commerce and Mobile Computing Technologies. United State Of America: IRM Press Publisher.

[14] Munawar. 2005. Pemodelan Visual Dengan UML. Yogyakarta: Graha Ilmu.

[15] Nugroho. 2004. Analisis dan Desain Sistem Informasi. Yogyakarta: Andi.

[16] Nugroho, Adi. 2005. Analisis dan Perancangan, Edisi Revisi. Bandung: Informatika Bandung.

[17] Nugroho, Bunafit. 2005. Database Relation Dengan MySQL. Yogyakarta: Andi.

[18] Nugroho, Dandy. 2012. Aplikasi Media Pemesanan Tiket Travel Berbasis Mobile Android Pada Baraya Travel. Bandung: Universitas Komputer Indonesia.

[19] Pressman RS. 2002. Rekayasa perangkat lunak. Terjemahan dari Software Engineering. Yogyakarta: Andi.

[20] Safaat, Nazrudin. 2011. Android : Pemrograman Aplikasi Mobile Smartphone dan Tablet PC. Bandung: Informatika

[21] Sumarso, Sonny. 2004. Metode Riset Sumber Daya Manusia. Yogyakarta. Graha Ilmu.

[22] Tim Penyusun Kamus Bahasa. 2008. Kamus Bahasa Indonesia. Jakarta: Pusat Bahasa.

[23] Tirso. Analysis of Competitiveness of Batangas State University College of Engineering Using Porter's Five Competitive Forces Model. Melbourne: Proceedings of the 2012 AAEE Conference.

[24] Valade, Janet. 2010. PHP \& MySQL for Dummies 4th Edition. Indiana: Wiley Publishing, Inc.

[25] Varshney, U., \& Vetter, R. (2001). A framework for the emerging mobile commerce applications. Proceedings of the 34th Hawaii International Conference on System Sciences.

[26] Whitten JL, Bentley LD, Dittman KC. 2004. Tim Penerjemah Andi, penerjemah Terjemahan dari: System Analysis and Design Methods. 2. Yogyakarta: Andi.

[27] Xiaojun, Ding et al. 2004. Unique Features of Mobile Commerce. Tokyo: Graduate School of Decision Science and Technology, TITECH.

[28] Zheing, Pei dan Ni, Lionel. 2006. Smartphone \& Next Generation Mobile Computing. San Fransisco: Morgan Kaufman.

[29] http://www.json.org/json-id.html diakses 712-2013 pukul 21.00WIB 